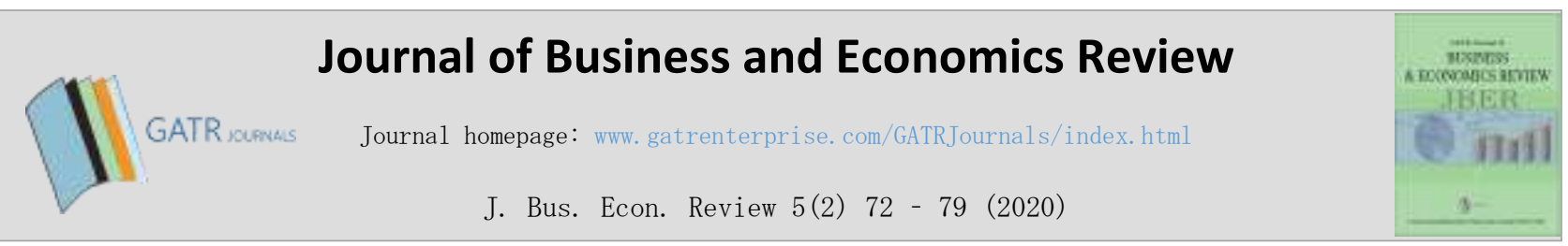

\title{
Migration and Remittances: Evidence from Cambodia, Myanmar and Lao Migrant Workers
}

\author{
Thitiwan Sricharoen
}

Faculty of Economics at Sriracha, Kasetsart University, Sriracha Campus, Tambon Tungsukha, Sriracha District, Chonburi, Thailand

\begin{abstract}
Objective - The purpose of research is to address and seek to answer leading questions concerning migration, with a focus on migration remittances, and management relating to remittance.

Methodology/Technique - The survey was conducted in 2018. In this study, a total of 511 migrant workers from Cambodia, Myanmar and Lao were interviewed. The methodology of this research applies a probit regression analysis.

Results - The findings show that repeated migrants who are not first-time migrants are a highly specific group with $54.74 \%$. First-time migrants are most likely to send remittances home while working in Thailand, accounting for approximately 2,826 Baht per month. However, this number decreases among second-time migrants who typically send remittances of approximately 2,331 Baht per month. The saving behavior is not different between first-time migrants and second-time migrants, who save a portion of their earnings. Nonetheless, this number rises to $50 \%$ for third and subsequent migrants. An estimation of all migrant's nationalities indicates that the variables that have the most influence on remittances in a positive way are: being of Cambodian nationality, experiencing a burden among their family, being in need of social assistance, being Myanmar migrants and household size, respectively. On the other hand, the variables that effect remittances in a negative way include: attaining below primary school education, education level (in year), real estate owned, and number of migrating household members in Thailand, respectively.

Novelty - The findings of this research show that those who graduate with less than primary level education are more likely to send money home compared to those who complete their primary school education. The policy recommendations made by this study include a recommendation that banks decrease money transferring costs, employers to pay salary through banking accounts and migrants to remit money through formal channels.
\end{abstract}

Type of Paper: Empirical.

JEL Classification: F22, F24, J61.

Keywords: International Migration; Remittances; Labor Mobility.

Reference to this paper should be made as follows: Sricharoen, T. (2020). Migration and Remittances: Evidence from Cambodia, Myanmar and Lao Migrant Workers, J. Bus. Econ. Review, $5(2) \quad 72 \quad-\quad 79$ https://doi.org/10.35609/jber.2020.5.2(3)

\section{Introduction}

Understanding why migrant workers send part of their income to their country of origin is central to the link between migration and development.

\footnotetext{
* Paper Info: Revised: July 22, 2020

Accepted: September 30, 2020

* Corresponding author: Thitiwan Sricharoen

E-mail: thitiwanthitiwan@gmail.com

Affiliation: Faculty of Economics at Sriracha, Kasetsart University, Sriracha Campus, Tambon

Tungsukha, Sriracha District, Chonburi, Thailand
} 
However, various complex forces affect remittance behaviour. These factors may include the number and nature of workers abroad and the level and type of economic activity in the sending and host countries. These factors determine the personal decisions made by migrants and their families about remittances (Russell, 1992). Remittances by immigrants to their country of origin is an extremely important source of income and sometimes the only source of income for their family members. Overall, migrant workers in Thailand have sent approximately $\$ 2.8$ billion through formal channels to Cambodia, Lao PDR, Myanmar and Vietnam (United Nation, 2019). People left behind in the countries of origin are positively affected by the receipt of remittances. Migrants who remit part of their earnings to their families can assist their family members with their living expenses and even to pay off their debt. Remittances also have a positive effect on the economic position of the origin country. Many governments see remittances from labor migration as providing great economic benefit. In many sending countries, international remittances are made after direct foreign investment. These financial inflows have a real positive effect in reducing poverty however there remains certain inequalities in this process (Carling, 2008).

The graph below presents the changes in migrant remittance inflow in Myanmar, Cambodia and Lao in a 10 year period from 2010 through to 2019. At the beginning of this period, the remittance inflow to those countries was low. There were a gradual increased until late 2012 when there was a sudden increase of remittance inflow to Myanmar from \$275 million to \$1,644 million in 2013. This higher remittance inflow to Myanmar has continued to rise considerably, reaching its peak of $\$ 3,035$ million in 2019. In Cambodia, from the end of 2010 there was a steady upward trend of remittance behavior beginning at $\$ 557$ million in 2010 and ending at over $\$ 1,500$ million in 2019. By contrast, the trend for remittance inflow to Lao is quite different. Lao households received fewer remittances during this period. The remittance inflow to Lao remained stable in 2010 and increased steadily but remained at around \$200 million (Figure 1).

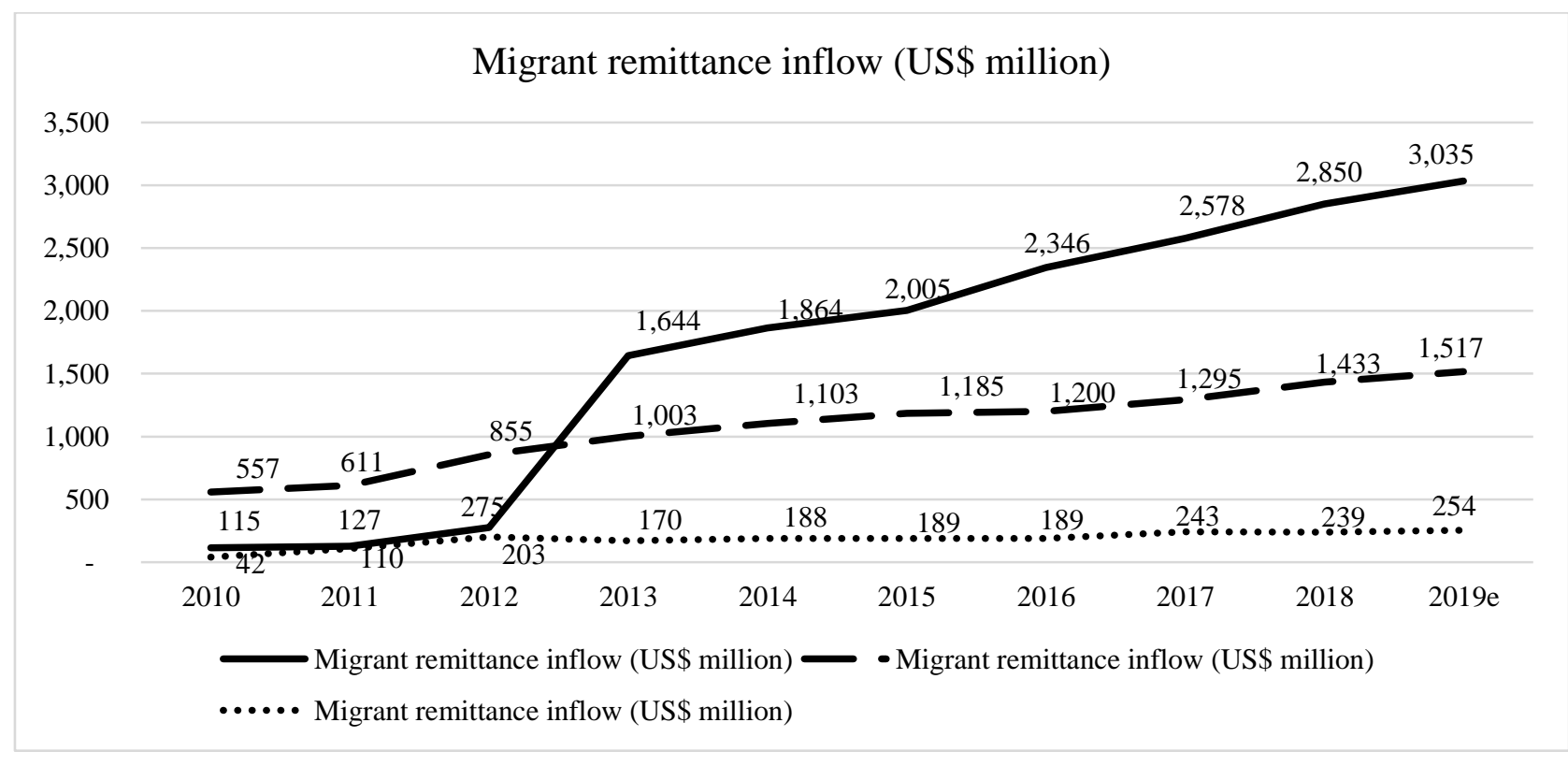

Figure 1. Migrant Remittance Inflow (US\$ million) to Myanmar, Cambodia and Lao, PDR

Source: World Bank, 2019. (Update as October 2019) 
The study focuses on empirical studies regarding the factors affecting the remittance of migrant workers working in Thailand, specifically, the reason for the difference in the amount of remittances between first time migrants and non-first time migrants. In addition, this research examines the working environment of migrant workers in Thailand. This research highlights existing issues with work and policy requirements to inform the development of work systems for migrant workers in Thailand.

\section{Research Methodology and Data Collection}

The main purpose of this research is to study remittances of migrants from Cambodia, Myanmar and Lao who work in Thailand. The analysis method used in this research is based on a survey of labor migration. After deleting any incomplete questionnaires, a total of 511 observations are used for analysis. The questionnaire is divided into 3 sections. Data was collected using specific random sampling. The research methodology applies a probit regression analysis. The described variables are separated into 5 categories, including: migration factors, demographic factors, hosting country factors, home country factors, and other factors.

\section{Literature Review}

Robert Lucas and Oded Stark (1985) examined the motivations to remit in Botswana, which has been cited almost 3 times more than any other journal article on remittances. Their analytical framework was an important element in the development of the so-called 'new economics of labor migration'. Decisions about remittances are linked with decisions about migration, and these decisions must be interpreted at the household level. These premises contrast with the traditional, neoclassical approach to labor migration as an individual investment in order to maximize lifetime earnings. Further, Oser's (1995) study on migrant remittance shows that the determinants of migrants' remittances are:

1. Personal characteristics such as age, age square, low education, high education, household size, nationality (Greece, Italy, Yugoslavia, and Spain), male;

2. Absorption indicators such as spouse living in home country, child in home country, years in Germany, remittance within one year, temporary migration, attending school in Germany; and

3. Income variables such as the family's net monthly income.

Holst and Schrooten (2006) studied labor remittance in Germany. The results of that study show that remittances increase with the variables of marriage, years of education, and employment. Remittances decrease with the variable of owning real estate in Germany. The variables that have no effect on remittances are income, receiving social assistance or unemployment benefits. Turkish residents prefer to remit more than other migrants. In addition, Carling's (2008) research on migrant remittance determinants identified the following factors which were found to influence remittance behaviour:

1. Personal and household characteristics;

2. Potential sender environment;

3. Other potential payee; Potential remittance receiver;

4. Personal and household characteristics;

5. Possible recipient environment;

6. Other potential remittance senders; 
7. Property of potential sender in the area of origin.

8. International money transfer routes; and

9. Sender-receiver relationship.

Deelen and Vasuprasat (2010) examined remittance of migrant workers from Thailand to Cambodia, Laos and Myanmar. Their data was collected from interviews and focus group discussions with 356 migrants in Thailand. In Laos, 200 remittance households were collected in Khammouane, Savanakhet, Saravan and Champasak provinces. In Cambodia, research teams interviewed 200 remittance households in Banteay Meanchey, Battambang, Pursat, Koh Kong and Kampot provinces. The research results indicate that migrants prefer to send money back through unofficial channels. Although official money transfer businesses such as Western Union and MoneyGram are located in most provinces in Cambodia and Laos, most local residents do not use these businesses due to the associated costs, lack of information and the satisfaction of using the services of informal remittances. It is suggested, particularly for Thailand, that access to financial services for migrants should be encouraged. An identity card can be used to open a bank account. Banks should reduce the costs of transferring money through the banking system. Finally, the right of foreigners to carry money back home when they visit home should be protected.

Lee, Sukrakarn and Choi. (2011) examined repeat migration and remittances among Thai workers. That research surveyed 519 Thai migrants across 6 countries: Taiwan, Hong Kong, Israel, Brunei, Singapore and South Korea. The results show that the variables that have an influence on remittances include:

1. number of times they have migrated;

2. second time migration;

3. third or more time migration;

4. age;

5. primary school education;

6. secondary school education;

7. higher secondary education;

8. being a registered labor worker with appropriate documentation;

9. marital status with no children;

10. being an immigrant in Hong Kong, Brunei, and other countries; and

11. Working in the service sector or labor sector.

\section{Research Findings}

Table 1 shows the regression results of the estimates for remittances classified by nationalities. The first equation is the estimation of sending remittances of all migrant's nationalities. The variables that have an influence on remittances in the same way are:

1. Being a Cambodian migrant;

2. experiencing a burden among the family;

3. requiring social assistance;

4. being a Myanmar migrant; and

5. Household size.

On the other hand, the variables that effect remittances in the opposite way are: 
1. Attaining below primary school education;

2. Education level (in years);

3. Real estate owned; and

4. Number of migrating household members in Thailand.

The research findings indicate that lower elementary school graduate migrants are more likely to send money home compared to those who achieve above elementary school education. The next equation concentrates on the likelihood of Cambodian migrants to send remittances. The results show that remittances have a positive correlation with first time migration and household size. These findings are consistent with the idea that first time migrant workers send most of their income to Cambodia but they are less likely to be economical compared to repeat migrants. Household size also has an effect on remittance. Migrants with large households are more likely to send remittances to support their relatives back home. However, remittances have a negative correlation with documented migrants, migrants with a single status and the number of migrating family members in Thailand. The reason for this is the high cost of registration for migrant workers, meaning they have less money to send home. In relation to status, single migrants are less likely to send remittances. The last variable is the number of family members in the destination country, which indicates that the more family members that live together in Thailand, the less remittances are sent.

The analysis of the third equation is related to Myanmar remittance behavior. The study shows that Myanmar migrants who send remittances have a strong positive correlation with social assistance, but a negative correlation with documented migrants, the number of months they have returned home in last 2 years, length of stay in Thailand and the number of migrating household members in Thailand. In relation to the correlation between social assistance and remittance, receiving social assistance has a significant influence on the remittance behavior among Burmese people because it helps them to save money, resulting in having a lot of money left for repatriation.

The next is the explanation about the variables that have a negative correlation with remittance. Documented migrants play it safe so that they can stay living aboard for longer by reducing their cost of living and also remittance frequency. Another variable is the number of months the migrants have returned home in last 2 years, Burmese people often take money home to reduce transaction costs. The more they go home and stay home for many months, the less money they remit. Further, migrants who stay longer in Thailand are expected to send remittances less frequently if they plan to settle down in a foreign country. Lastly, the number of migrating household members in Thailand has an effect on remittance behavior in the opposite way. When the number of migrants from the source household increases, those migrants will be less likely to send remittances because close relatives already live in the sending country together.

The fourth equation deals with Lao migrants. In order of highest to lowest, remittance among Loa migrants is correlated positively with documented migrants, burden of family, household size and amount of income. In the case of Lao migrants, being documented migrants may enable them to earn more income so they are able to send remittances home. Further, migrants with many family responsibilities send remittances more regularly. Migrants in large families tend to send a lot of money home to support their family's living costs. Remittances increase with per capita income however in this case, income has no significant impact on remittances. On the other hand, the prevalence of sending remittances among Lao migrants has a negative correlation with real estate owned, saving, and male status, respectively. Migrants who have their own home in their hometown show that they have a certain level of wealth, so they will send less money back home. Further, migrants who tend to be more economical are less likely to send money to remit because saving is vital to their future. Ultimately, Lao male migrants are less likely to send remittances because males typically spend more money. 
Table 1. Probit Regression Analysis on Remittances Classified by Nationalities

\begin{tabular}{|c|c|c|c|c|}
\hline & $\begin{array}{c}\text { Remittances } \\
\text { sending } \\
\text { (Total) }\end{array}$ & $\begin{array}{l}\text { Remittance } \\
\text { sending } \\
\text { of Cambodian } \\
\text { migrants }\end{array}$ & $\begin{array}{l}\text { Remittance } \\
\text { sending } \\
\text { of Myanmar } \\
\text { migrants }\end{array}$ & $\begin{array}{c}\text { Remittance } \\
\text { sending } \\
\text { of Lao } \\
\text { migrants }\end{array}$ \\
\hline & Equation 1 & Equation 2 & Equation 3 & Equation 4 \\
\hline Saving & & & & $\begin{array}{l}-0.793 \\
(0.000)\end{array}$ \\
\hline First time migration & & $\begin{array}{c}0.763 \\
(0.004)\end{array}$ & & \\
\hline Male & & & & $\begin{array}{l}-0.660 \\
(0.050)\end{array}$ \\
\hline Education (in year) & $\begin{array}{l}-0.622 \\
(0.001)\end{array}$ & & & \\
\hline Below primary school & $\begin{array}{l}-0.846 \\
(0.003)\end{array}$ & & & \\
\hline Social assistance $($ yes $=1)$ & $\begin{array}{c}0.586 \\
(0.000)\end{array}$ & & $\begin{array}{c}0.968 \\
(0.003)\end{array}$ & \\
\hline Income(amount) & & & & $\begin{array}{c}0.000 \\
(0.005)\end{array}$ \\
\hline Register/Documented migrant & & $\begin{array}{l}-0.758 \\
(0.028)\end{array}$ & $\begin{array}{l}-1.405 \\
(0.017)\end{array}$ & $\begin{array}{c}3.163 \\
(0.000)\end{array}$ \\
\hline Single & & $\begin{array}{l}-0.553 \\
(0.033)\end{array}$ & & \\
\hline Household size & $\begin{array}{c}0.096 \\
(0.002)\end{array}$ & $\begin{array}{c}0.202 \\
(0.005)\end{array}$ & & $\begin{array}{c}0.131 \\
(0.005)\end{array}$ \\
\hline Real estate owned (yes $=1$ ) & $\begin{array}{l}-0.360 \\
(0.009)\end{array}$ & & & $\begin{array}{l}-1.015 \\
(0.011)\end{array}$ \\
\hline Visit home in the last 2 & & & $\begin{array}{l}-0.074 \\
(0.150)\end{array}$ & \\
\hline Length of stay in Thailand & & & $\begin{array}{l}-0.072 \\
(0.049)\end{array}$ & \\
\hline Cambodia $($ yes $=1)$ & $\begin{array}{c}0.967 \\
(0.000)\end{array}$ & & & \\
\hline Myanmar (yes=1) & $\begin{array}{c}0.404 \\
(0.031)\end{array}$ & & & \\
\hline $\begin{array}{l}\text { Number of migrating household } \\
\text { members in Thailand }\end{array}$ & $\begin{array}{l}-0.221 \\
(0.000)\end{array}$ & $\begin{array}{l}-0.211 \\
(0.003)\end{array}$ & $\begin{array}{l}-0.284 \\
(0.000)\end{array}$ & \\
\hline Burden of family & $\begin{array}{c}0.684 \\
(0.000)\end{array}$ & & & $\begin{array}{c}2.044 \\
(0.000)\end{array}$ \\
\hline cons & $\begin{array}{c}0.237 \\
(0.657)\end{array}$ & $\begin{array}{c}0.545 \\
(0.040)\end{array}$ & $\begin{array}{c}1.806 \\
(0.000)\end{array}$ & $\begin{array}{l}-5.044 \\
(0.000)\end{array}$ \\
\hline $\mathrm{N}$ & 511 & 211 & 150 & 150 \\
\hline Pseudo R2 & 0.238 & 0.101 & 0.267 & 0.569 \\
\hline
\end{tabular}

Source: Own calculation. 
Note: Value in bracket is $\mathrm{P}>|\mathrm{z}|$.

\section{Policy Discussion and Conclusion}

The policy recommendations of this research on remittance are as follows. Firstly, Thai commercial banks should decrease the costs associated with transferring money overseas for foreign workers in order to incentivize them to use banks for their international money transfers. Secondly, governments should persuade Thai employers to pay their salaries through banking accounts and invite migrants to establish long-term savings in Thailand. Some migrants may not be interested in establishing a savings account in Thailand, but they may be interested in purchasing property or luxury goods instead. Hence, banks should sell their products to those migrants and persuade them to remit things instead of money.

Thirdly, the government should encourage migrants to remit money through formal channels to enable the government to monitor the amount of remittance cashflow. Fourthly, governments should promote a variety of choices for conducting money transfers such as Western Union. Fifthly, the government should allow migrant workers to change employers and move across provinces without approval of the Thai government, to avoid their migrant status being revoked and to encourage them to use formal channels for their remittances. Sixthly, the government should develop innovative financial products for use by migrants. Finally, the government should relax the applicable regulations and allow migrants to bring family members to stay in Thailand to reduce the remittance outflow from Thailand because remittances account for a high percentage of the GDP.

\section{Acknowledgements}

The author would like to express sincere gratitude to Kasetsart University Research and Development Institute for supporting the research budget. Further thanks are given to all of the migrant workers who were so generous with their time in completing the questionnaire surveys. The author also thanks the faculty members for their support.

\section{References}

Akee, R., \& Kapur, D. (2017). Myanmar remittances. International Growth Centre: London, UK. https://www.theigc.org/wp-content/uploads/2018/06/Akee-and-Kapur-2017-Final-report.pdf

Carling, J. (2008). The determinants of migrant remittances. Oxford Review of Economic Policy, 24(3), 581-598.

Deelen, L. \& Vasuprasat, P. (2010). Migrant workers' remittances from Thailand to Cambodia, Lao PDR and Myanmar. Report. ILO/Japan Project on Managing Cross-border Movement of Labor in Southeast Asia.

Holst, E., \& Schrooten, M. (2006). Migration and money: What determines remittances? Evidence from Germany (No. 566). DIW Discussion Papers. https://www.econstor.eu/handle/10419/18459

Lee, S. H., Sukrakarn, N., \& Choi, J. Y. (2011). Repeat migration and remittances: Evidence from Thai migrant workers. Journal of Asian Economics, 22(2), 142-151. https://doi.org/10.1016/j.asieco.2010.11.005

Lucas, R. E., \& Stark, O. (1985). Motivations to remit: Evidence from Botswana. Journal of political Economy, 93(5), 901-918. https://www.journals.uchicago.edu/doi/pdfplus/10.1086/261341

Oser, U. (1995). Remittances of guest workers to their home countries: an econometric analysis (No. 25). Discussion Paper, Center for International Labor Economics (CILE), University of Konstanz. https://www.econstor.eu/handle/10419/92439

Russell, S. S. (1992). Migrant remittances and development. International migration (Geneva, Switzerland), 30(3-4), 267. https://www.ncbi.nlm.nih.gov/pubmed/12286971

Turnell, S., Vicary, A., \& Bradford, W. (2008). Migrant-worker remittances and Burma: an economic analysis of survey results. http://library.oapen.org/bitstream/handle/20.500.12657/33774/458944.pdf?sequence=1\#page=73 
Harkins, B. (2019). Thailand migration report 2019. Bangkok: United Nations Thematic Working Group on Migration in

Thailand.

https://hailand.iom.int/sites/default/files/document/publications/Thailand\%20Report\%202019_22012019_HiRes.pdf World Bank. (2017). Bilateral remittances matrix 2017. Retrieved January 6, 2020, from http://www.worldbank.org World Bank. (2019). Migration and remittances data. Retrieved February 1, 2020, from http://www.worldbank.org 